\title{
Jessica Derleth
}

\section{"KNEADING POLITICS": COOKERY AND THE AMERICAN WOMAN SUFFRAGE MOVEMENT}

During the American woman suffrage movement, opponents described suffragists as abnormal, unsexed, non-mothers who desired to leave the home and family en masse, levying "war against the very foundation of society." This charge ultimately compelled suffragists around the nation to respond by embracing expediency arguments, insisting the women's votes would bring morality, cleanliness, and order to the public sphere. This article charts how suffragists capitalized on movements for home economics, municipal housekeeping, and pure food to argue for the compatibility of politics and womanhood. In particular, this article examines suffrage cookbooks, recipes, and bazaars as key campaign tactics. More than a colorful historiographical side note, this cookery rhetoric was a purposeful political tactic meant to combat perennial images of suffragists as "unwomanly women." And suffragists ultimately employed the practice and language of cookery to build a feminine persona that softened the image of their political participation and made women's suffrage more palatable to politicians, male voters, potential activists, and the general public.

\section{INTRODUCTION: "OF DINNERLESS FAME"}

In late August of 1913, Joseph McGrane stood before a magistrate and packed courtroom charged with beating his wife. Denying the accusation, McGrane implored those assembled to understand the difficulty of his situation: "I have reached the point where I can stand it no longer. No militant suffragette has anything on my wife. She has made the last few years of my life unbearable. Why, your Honor, I am cook, housekeeper, and man-of-all-work about our place."1 McGrane expressed fraternity with other husbands of suffragist wives, specifically urging reporters to provide him with the address of Lawrence Rupp. Earlier that month Lawrence made headlines from California to Montreal after publicly protesting his wife's activism. On August 7, 1913, as Maria Rupp took the podium at a public meeting on behalf of women's right to vote, Lawrence interjected. By one newspaper account, Lawrence yelled across the crowded meeting: "Maria, come home. That's where your place is, getting me my supper, and not out here on a street corner making speeches about woman's suffrage."2 Another newspaper reported that Lawrence incited young boys to heckle Maria with chants of "go home to your husband and kids. This man hasn't had supper in six months!" 3 Unable to calm her husband, Maria had him arrested for disorderly conduct. Public reactions ranged from amusement to alarm, with a Cincinnati newspaper reporting that both suffragists and 
antisuffragists condemned Maria: suffragists maintained that "no good suffragist should permit the cause to interfere with her home duties [and] Mrs. Rupp should have prepared her husband's supper before going out to speak," while antisuffragists declared that she had stepped beyond her sphere and that "cooking is more useful than soap box oratory." 4 While Lawrence "of dinnerless fame" spent the night in prison, newspapers throughout the country remarked on this "politico-domestic precedent" and fed a national discussion about suffragists and their relationship to their husbands, household duties, and domestic harmony. 5

More than a missed meal, the Rupp marital dispute represented genuine anxieties about the social and cultural changes posed by women who sought formal political rights during the late nineteenth and early twentieth centuries. Gender norms of this era idealized men and women as complementary but binary opposites: men had a natural, God-given duty to work in the public sphere while women had similar obligations to the private realm of home and children. ${ }^{6}$ The "true woman" remained apart from the public realm of politics, economics, and business. Significant changes in the nineteenth century, however, expanded the public roles open to women. Americans increasingly accepted women who engaged in politics through non-electoral channels by serving on education committees, entering into dialogue about public concerns, and taking a hand in municipal affairs. ${ }^{7}$ Many Americans believed that women possessed domestic expertise that enabled them to protect the home from the public sphere. Thus, they valued women as moral guides for their husbands and children but could not always reconcile the idea of female domesticity with formal, electoral political participation. Antisuffragists capitalized on these fears by portraying suffragists as unwomanly, unsexed, abnormal, non-mothers who would leave the home and family en masse, levying "war against the very foundation of society." 8

Food was a key component of these gendered antisuffrage arguments. Antisuffragists argued that women involved in the campaign for the vote lacked culinary skills, failed to cook for their husbands, and did not care that their children went hungry in their absence. With these claims, antisuffragists insinuated much more than inattention to food preparation: suffragists failing to fulfill their culinary obligations showed disregard for their homes, families, and duties as women. Thus, antisuffragists condemned Maria Rupp for failing to prepare her husband's nightly meal because her disregard of his needs signaled a dangerous disruption of gender roles.

Antisuffragist criticism of Maria Rupp tapped into broader anxieties about changes in gender, but the suffragist concurrence hints at how women's rights advocates embraced gender norms to prove their cause was nonthreatening. Like their opponents, suffragists recognized that when Lawrence Rupp did not get his dinner there was much more at stake than a satisfying meal. The historian Elna Green observes that women on both sides of the suffrage debate knew they needed to appeal to hearts and minds. Both sides, consequently, "crafted rhetoric and imagery with purposefully emotional cores." In doing so, they created "useful stereotypical images" meant to "influence popular perceptions." 9 Just as antisuffragists appealed to popular sentiments about gender and food, so did suffragists. This article argues that suffragists challenged claims that they abandoned the kitchen by embracing the culinary arts to demonstrate that they accepted many dominant gender expectations. In responding to antisuffrage claims, suffragists used the practice and language of cookery to build a feminine persona for their movement and to 
demonstrate that enfranchising women would not threaten the vital institutions of home and family. By compiling cookbooks, publishing recipes, and hosting bazaars, suffragists from around the nation engaged in a public dialogue about the compatibility of politics and womanhood. By writing about food and displaying cooking skills, suffragists demonstrated their ongoing commitment to dominant gender expectations even as they demanded the right to vote.

Despite the pervasiveness of suffrage cookery rhetoric between 1880 and 1920, historians have not recognized the role it played in suffragists' expediency tactics in the late nineteenth and early twentieth centuries. With her 1965 seminal work, the historian Aileen Kraditor described a shift within the suffrage movement from rights-based activism to arguments based on expediency: while the early movement lobbied for the ballot in the name of justice and natural rights, suffragists in the twentieth century insisted that woman suffrage was practical and beneficial to society. ${ }^{10}$ In contrast to more egalitarian right-based arguments, suffragists' expediency arguments typically reinforced race and class hierarchies by arguing that only morally superior middle- and upper-class white women could effectively wield the ballot alongside white men. ${ }^{11}$ Although "rights based" and "expediency" remain useful categories of pro-suffrage arguments, historians have overturned Kraditor's chronological shift from one tactic to another beginning in the 1890s. Scholars instead acknowledge that both arguments coexisted and that white leaders often bolstered class and race hierarchies throughout the course of the movement. ${ }^{12}$ Although the historiography has moved away from a declension model where racist and classist expediency arguments displaced the egalitarian approach of the early suffrage movement, many scholars continue to describe gendered expediency arguments as corrupting "more pure" feminist roots. ${ }^{13}$ One historian, for example, argues that "hard-core feminism" was "gradually displaced by social feminism," which moved away from "a premise of equality between the sexes" to emphasize a unique female essence that would improve politics. This shift both "helped detach the vote from a larger feminist program" and contributed to the "depoliticization" of the "movement's original challenge to female subordination." 14

This article argues against this declension narrative. I demonstrate how suffragists' deployed cookery as one of several expediency arguments to revitalize their movement in the late nineteenth and early twentieth centuries. Suffragists' emphasis on domesticity coincided with the merger of the National Woman Suffrage Association and the American Woman Suffrage Association that resulted in the National American Woman Suffrage Association (NAWSA). With this consolidation of the most prominent and national forces in the suffrage movement, NAWSA began excluding radical or unseemly elements of the movement. ${ }^{15}$ The organization's decision to avoid divisiveness largely came from leaders who believed that the radical tactics of the past had proved ineffective and that a new course of conservative rhetoric would be more effective in educating the public. ${ }^{16}$ Suffragists' focus on women as "the nurturers of society" offered a means to assure a hesitant public that the franchise would help women solve social ills, a tactic that posed less of a threat to the status quo than rights-based arguments. ${ }^{17}$ These expediency argumentsincluding cookery rhetoric - reinforced race, class, and gender hierarchies. Acknowledging that this strategy did not represent a break from an "egalitarian" or "more feminist" suffrage movement, however, allows this article to chart how and why suffragists embraced and manipulated dominant gender expectations through cookery rhetoric. 
By considering food as a tactical element of the movement, this article forces a reinterpretation of the so-called suffrage doldrums - the years between 1885 and 1910 that historians typically describe as an era of inactivity marked by little success. ${ }^{18}$ The suffrage movement's politicization of food culture, however, emerged in the 1880s and proliferated in the 1910s. In line with the scholarship of historian Sara Hunter Graham, this study of cookery shows that this period was actually a "suffrage renaissance" marked by active reorganization, reevaluation of tactics, and changes in political strategy. ${ }^{19}$ Expediency arguments about food and domesticity did not represent an ideological or organizational declension; rather they indicate one way in which suffragists revitalized their movement by politicizing municipal housekeeping rhetoric and the emergent home economics movement.

Finally, examining cookery rhetoric in the woman suffrage movement means reevaluating the role of gender expectations, realizing that they did more than constrict and limit the fight for women's rights. While scholars acknowledge the existence of suffrage cookbooks and bazaars, they generally relegate these political tools to a colorful side note. ${ }^{20}$ One historian's deeper analysis of suffrage bazaars characterizes domestic ephemera as unintentionally upholding traditional gender expectations. ${ }^{21}$ At the same time, another scholar similarly argues that when NAWSA adopted socially acceptable tactics it "played directly into the hands of patriarchy." 22 These scholars, among countless others, rightly observe the restrictive nature of domesticity, which reinforced not only gender but also race and class. This "kitchen culture"-encompassing everything from cooking utensils to recipes to food advertisements- has long constructed gender roles and outlined ways to perform womanhood. ${ }^{23}$ Racial, religious, and evolutionary theories of the late nineteenth and early twentieth centuries added further weight to these gender prescriptions by arguing that dichotomous gender roles marked the supposed civility and superiority of the white race. ${ }^{24}$ Food thus functioned as a marker of race and class status; euthenics, for instance, brought together women from the eugenics and home economics movements to cultivate a superior (white) race through better breeding and nutrition science. ${ }^{25}$ While reaffirming the ability of kitchen culture to define gender boundaries, this article primarily focuses on how women used cookery rhetoric to resist gender restrictions. When suffragists discussed diet and food production they did not simply parrot the tropes of domesticity; rather, they capitalized on widespread public concerns and conversations-about health and safety, science and modernization, and the consequences of urbanization - to promote the cause of female enfranchisement. Suffragists hosted bazaars and sold cookbooks as purposeful political tactics that directly responded to charges of masculinity and unwomanly behavior by softening the image of the movement. This article thus calls for historians to reevaluate the myriad ways that suffragists co-opted the dominant discourse on womanhood. Far from corrupting the ideology and objectives of the suffrage movement, cookery proved a politically savvy tactic to combat the perennial image of suffragists as unwomanly women and gain the movement greater public support.

HOME ECONOMICS AND A BETTER TYPE OF COOKING

The late nineteenth-century United States experienced profound changes in the production, consumption, and politics of food as the national food system underwent industrial 
modernization. ${ }^{26}$ With the rise of corporate agriculture and food processing, Americans increasingly ate grains grown hundreds of miles from where they lived, cooked meats transported in refrigerated railcars, and purchased packaged foods at the local grocer. ${ }^{27}$ The technological changes that assisted the rise of commercial food production also appeared in private homes: iron stoves and ranges made it possible for middle-class Americans to create more elaborate dishes, feeding a demand for cookbooks and domestic manuals. ${ }^{28}$ Although poor and rural Americans did not have immediate access to these technologies, new kitchen tools and domestic conveniences spread quickly in the late nineteenth and early twentieth centuries. ${ }^{29}$ As early as the 1880s, urban reformers realized that this industrialization generated significant sanitary, dietary, and food safety problems, and they sought to improve the nation by changing the eating habits of all Americans. ${ }^{30}$

In the late nineteenth century, the nascent home economics movement developed alongside broader middle-class and progressive reform efforts focused on improving food safety and eating habits. That century also witnessed a virtual cookbook revolution as American women turned away from European culinary instructions to pen their own cookbooks and domestic manuals on food preparation, frugality, temperance, and practical home management. Emerging from this wave of female culinary writers, Catharine Beecher emphasized the importance of studying the role of women in the home and insisted that women apply business principles to domestic labor. ${ }^{31}$ This cooking culture combined with the falling price of exotic ingredients, the availability of processed foods, and the sale of new kitchen gadgets to make it easier for middle-class women to imitate the dining habits of the upper class (although they often did so with far less domestic help). ${ }^{32}$ This cooking revolution prepared an educated middle class, "more awed by modern scientific wisdom," to accept the purported "science and professionalism" of food reformers and home economists by the turn of the twentieth century. ${ }^{33}$

Even before the first organized meeting of home economists in 1899, suffragists capitalized on this particular moment when cooking and food instruction became increasingly important to the middle class by publicly espousing the value and importance of scientific cookery. Reviews of cookbooks in major suffrage newspapers, for example, demonstrated an interest in cookery and a commitment to healthful food, nutrition, and sanitation. ${ }^{34}$ Articles on household tips ranged from childcare to laundry instructions, sanitizing fruit cans, and how to reduce waste. ${ }^{35}$ Many of these articles emphasized the weighting and measuring of ingredients, included timetables for managing the kitchen, and offered "simple, sensible" recipes with "practical and minute instructions." 36 This suffrage domestic advice aligned with early home economists who hoped to adjust American attitudes toward food, making their behaviors in the kitchen more rational, scientific, and healthy. ${ }^{37}$

Early suffrage cookbooks drew on ideals of scientific home management, making subtle connections between their cause and the budding home economics movement (which, again, did not formally organize until 1899). The Woman Suffrage Cookbook (1886 and 1890), for example, often called for specific kitchen tools, precise temperatures, exact cooking methods, and careful measurements. ${ }^{38}$ Suffragists' scientific and rational approach to food extended to many of the recipes, which instructed readers to control and manage food, creating casseroles with neat layers or forming ingredients into tidy spheres. ${ }^{39}$ Several recipes, provided by suffragists active in the home economics 
movement, such as May Wright Sewall, promised that the resulting dish would provide an odor appealing enough to trigger appetite- a physiological concern for home economists. ${ }^{40}$ Mary J. Safford also submitted Frances Willard's "Protest Against Pepper" to the cookbook (both women supported home economics). Warning against pepper as the "abomination to the sense of every normal stomach," Willard stood for "stomachic rights," "plain living and high thinking." ${ }^{41}$ First published in the 1880s, suffrage cookbooks, recipes, and domestic advice articles grew out of connections between women's rights advocates, food reformers, and the emergent home economics movement; these connections strengthened by the 1910s as suffrage cookbooks and recipes became an integral part of the movement and explicitly drew from an organized and established home economics movement.

The Progressive Era, with its emphasis on scientific explanations and social reform, created the space for a national movement that would transform American eating habits. ${ }^{42}$ This domestic reform movement—varyingly known as scientific housekeeping, home science, progressive housekeeping, scientific cooking, and domestic science-ultimately called itself home economics. ${ }^{43}$ Intent on professionalizing domestic labor, the home economics movement sought to bring science, rationality, and modernity to the work of running a household. ${ }^{44}$ Home economists studied nutrition, crafted balanced recipes, observed the physical and chemical processes of eating, sought the most rational ways to organize the kitchen, and pushed for a nation of women trained to run efficient households. Making the home a "more businesslike place," they argued, would improve the home, elevate the work of women, and strengthen the nation. ${ }^{45}$ Home economics "required a significant cultural shift" as physical labor within the home veered away from associations with servitude, gaining prestige that called for the modern housewife to embrace domestic labor as the embodiment of her intelligence and familial love. ${ }^{46} \mathrm{Far}$ removed from the political radicalism of early food reform and steeped in the scientific rationality of the Progressive Era, leaders within universities, public schools, the food industry, and women's clubs began to propagate home economics. ${ }^{47}$ By the 1910s, middle-class Americans were well versed in the ideals, rationale, and practices of the movement, by then a core component of many cookbooks. ${ }^{48}$ And like other progressive reformers, many suffragists supported home economics. ${ }^{49}$ Suffragists, however, did not just join the home economics movement- they capitalized on its popularity to promote votes for women.

Building on awareness of home economics and drastic changes to American foodways, antisuffragists at the turn of the twentieth century argued that suffragists encouraged women to leave their kitchens and abandon the American home when the family and nation most needed them. Although diverse groups and individuals opposed the suffrage movement for more than seventy years, antisuffrage arguments often implicitly and explicitly tapped into conventional gender ideologies: in doing so they came back to foundational ideas about womanhood, the natural role of women, and the potential consequences of violating these norms. ${ }^{50}$ Antisuffragists thus frequently described suffragists as working against the best interests of the home and family. One antisuffragist in 1905, for example, argued: 'The word 'housewife,' is a mockery to those suffragists [who] want to be out all the time." ${ }^{51}$ Another author urged suffragists to stop "influencing your weaker sister to neglect her housework and get out and clamor for suffrage." Instead, suffragists needed to realize that "the home is the real thing in this world" and 
women must "rule over it like a queen [for] its duties are endless." 52 Suffragists abandoned their home duties in favor of politics, obviously not caring about the food challenges that faced the modern home.

Suffragists drew from the popularity of the home economics movement in responding to antisuffragists, explicitly linking female enfranchisement to improved, scientific cookery. By printing recipes for "suffrage savories" or "spaghetti a la suffragette" suffragists linked the ballot with cooking and declared, "We are all hungry for something new in the way of eatables, as well as for votes." ${ }^{53}$ Suffragists brought together the ideal foods and the latest cooking methods and promised to "secure the maximum nourishment with the minimum expense." ${ }^{54}$ Newspapers noticed, and sometimes applauded, suffragists' use of home economics principles. In direct contrast to antisuffrage predictions, the Friend's Intelligencer argued in 1909 that suffrage was more likely to improve than destroy the home: "[Female suffrage] will, in all probability, change the home very materially. It will make it better, something more consonant with the present stage of the world's development. It will bring the home up to date, make it a twentieth-century home. ${ }^{" 55}$ By the 1910s, suffragists worked to demonstrate that as educated, thoughtful, and conscientious citizens, women's rights advocates and enfranchised women could improve modern home life. New York suffragists blended scientific cookery and enfranchisement in a 1916 cookbook that argued, "Preparedness in the Home' and 'Vote for Women' stand together." Their ideal home was simplified, efficient, and based on practical equipment. By designing their cookbook around electrical appliances-coffee percolators, oblong grills, electric freezers, portable ovens, waffle irons, and chafing dishes-these middle-class suffragists embraced home economics and modern technology so that "woman's usefulness to the community and the home [will] be widened." They also explicitly connected enfranchisement to scientific cooking, arguing that the vote would empower women to use their knowledge of the home to improve the public and private realms: "With learning, wit, and strength and heat/ The hour is not remote/ When women from their drudgery freed/ Will all the nation wisely feed/ And scour with the vote." 56

Although suffragists worked in the home economics movement and drew from its approach to rational home management, their discussion of scientific cookery differed because of their focus on politics, gender inequality, and voting rights. As suffrage cookery texts first emerged, the two movements subtly diverged in how they discussed food. Emblematic of this is how suffragists and home economists described drudgery. Home economists argued that the constant exhaustive labor of women that pitted them against malnutrition, poison, disease, and waste turned them into drudges who perpetually fought the miseries of the home. ${ }^{57}$ Home economists gladly embraced the private sphere as the location of true womanhood, but they argued that women needed scientific cookery to "both lift and clarify the status of the woman in charge of the kitchen." ${ }^{58}$ Battling drudgery would thus improve the quality of women's work, forcing society to recognize the importance of her labor and elevate her status. ${ }^{59}$ Suffragists similarly acknowledged that the joys of running a household and caring for a family could become irksome and devolve into drudgery. ${ }^{60}$ The first four volumes of The History of Woman Suffrage (published between 1881 and 1902), for example, frequently referenced "domestic drudgery" and the relegation of women to the role of "household drudge." ${ }^{\prime 1}$ Unlike home economists, The History linked domestic drudgery to sex 
inequality. Quoted in the first volume, Ann Preston argued: "To be an ornament in the parlor or a mere drudge in the kitchen, to live as an appendage to any human being, does not fill up nor satisfy the capacities of a soul awakened to a sense of its true wants, and the far-reaching and mighty interests which cluster around its existence."62 Although many likely believed in the merits of scientific cookery as earnestly as any home economist, suffragists identified the home as a site of sex and gender oppression. Whereas home economists generally avoided discussing women's rights or politics, suffragists linked scientific cookery and food with the public role of women and formal political rights. ${ }^{63}$ Like historians who dismiss suffragists' gendered expediency arguments as harmful to the movement, some scholars criticize the home economics movement for choosing "domesticity as a way of getting out of the house." 64 As this article illustrates, however, women wielded cookery, domesticity, and food as powerful tools against gendered social and political restrictions.

\section{THE POLITICAL UTILITY OF FOOD}

In the twentieth century, suffragists capitalized on changing understandings and valuations of domesticity that increasingly saw work within the home (from cooking to childcare) as a significant sphere of daily life. ${ }^{65}$ Like clubwomen around the nation, suffragists identified a range of social problems - from poor housing, to child labor, and inadequate education - that women could help men remedy. ${ }^{66}$ Through the rhetoric of municipal housekeeping, these women emphasized the similarities between the home and city, arguing that women's unique skills made them ideally suited to lead civic betterment projects. ${ }^{67}$ In particular, municipal housekeeping advocates pointed to air quality, food purity, and city sanitation as domestic concerns. Much like the home economics movement, municipal housekeeping germinated in shifting understandings about the meaning and value of women's domestic labor. And municipal housekeeping, in part, became incredibly popular with women's clubs because it was a nonpolitical term that justified women's entry into public spaces and encouraged women to undertake a variety of reform work in their communities. ${ }^{68}$ Municipal housekeeping, however, took on new political meanings in the context of the suffrage movement. As they did with home economics, suffragists politicized municipal housekeeping. By embracing municipal housekeeping - and capitalizing on its emphasis on femininity and domesticity-suffragists justified the expansion of the franchise in language consonant with popular ideas about gender. Viewed in this way, scholars will struggle to dismiss the political utility of domesticity and to characterize the years between 1885 and 1910 as a suffrage doldrums.

By the early twentieth century, suffragists frequently and consistently argued that private and public concerns were both deeply intertwined and highly political. Writing in the suffrage newspaper The Yellow Ribbon in 1907, for example, recent NAWSA president Carrie Chapman Catt observed: "It is sometimes thought that politics deals with matters difficult to understand, and quite apart from affairs of the home." Catt assured women, however, that politics permeated their homes and domestic concerns-from the food on their family table to the vaccinations mandated for their children. She argued that the only solution was to "seat the 'Queen of the Home' upon the throne of government beside the 'King of Business,' and let them rule together." 69 While 
reinforcing women's responsibility for clean homes, safe food, and healthy children, suffrage pamphlets argued that many factors influencing the physical condition of the home remained beyond a woman's control and suffragists wanted the vote precisely because of their dedication to the private sphere: one suffragist insisted, "I am a housekeeper. Even the antis will allow that that is a perfectly proper thing for me to be" (see Figure 1). ${ }^{70}$ Drawing on the rhetoric of municipal housekeeping, suffragists insisted that the only way for society to improve conditions that bridged public and private life was to allow women to use their unique talents: "Women are, by nature and training, housekeepers. Let them have a hand in the city's housekeeping, even if they introduce an occasional house-cleaning." 71

Such municipal housekeeping arguments drew significant numbers of women and men into the suffrage movement and were a key factor in state victories. Cities in Illinois and California, for instance, experienced a surge in women's municipal activism before the development of a strong suffrage movement. These women often worked together with men for the sake of urban reform and development, seeing their work as a civil rather than political effort. Through this activism many women came to see themselves as political actors and the ballot as a tool for civic betterment; and these broad movements for good government evolved into suffrage coalitions that crossed gender, racial, ethnic, and class lines. ${ }^{72}$ Historians argue that suffragists' emphasis on the ballot as a practical tool for women to extend their domestic skills and morality to the public sphere brought the suffrage movement both the endorsement of many clubwomen and much wider public support. ${ }^{73}$ In fact, some scholars list municipal housekeeping arguments as a crucial factor in states granting women the right to vote years or even decades before the federal amendment. ${ }^{74}$ More so than in any other region, western suffragists actively changed their arguments to emphasize that enfranchised women would remedy dangerous social conditions (from drinking and gambling to prostitution). And these expediency arguments helped them win the vote because they resonated with widespread gender norms ${ }^{75}$ Suffragists were cognizant of the broad appeal of these argumentswhich fostered alliances with municipal reformers and clubwomen and spurred success in the West—and included them in their regional and national arsenal of political tactics.

Although suffragists employed many municipal housekeeping arguments, historians generally overlook their acuity in capitalizing on widespread fears about industrial food production and food safety. For many Americans, food fundamentally changed in the late nineteenth and early twentieth centuries as big businesses increasingly transported, transformed, and marketed processed foods. ${ }^{76}$ Technological developments did not just allow companies to package food, but also to chemically preserve it, mask signs of decomposition, alter colors and flavors, and add fillers; profit-driven, "unscrupulous food producers" used these adulterations as manufacturing shortcuts. ${ }^{77}$ Food safety then entered the national spotlight at the turn of the twentieth century through the work of journalists, food reformers, home economists, and clubwomen. ${ }^{78}$ Whereas home economists avoided explicitly connecting impure food and politics, suffragists utilized widespread fears about unreliable food manufacturing to argue for their cause. ${ }^{79}$ For instance, the title page of the 1916 Choice Recipes Compiled for the Busy Housewife, sponsored by the Clinton Political Equality Club, quoted well-known food chemist Dr. Harvey Wiley on female enfranchisement as the solution to impure food: "If the 

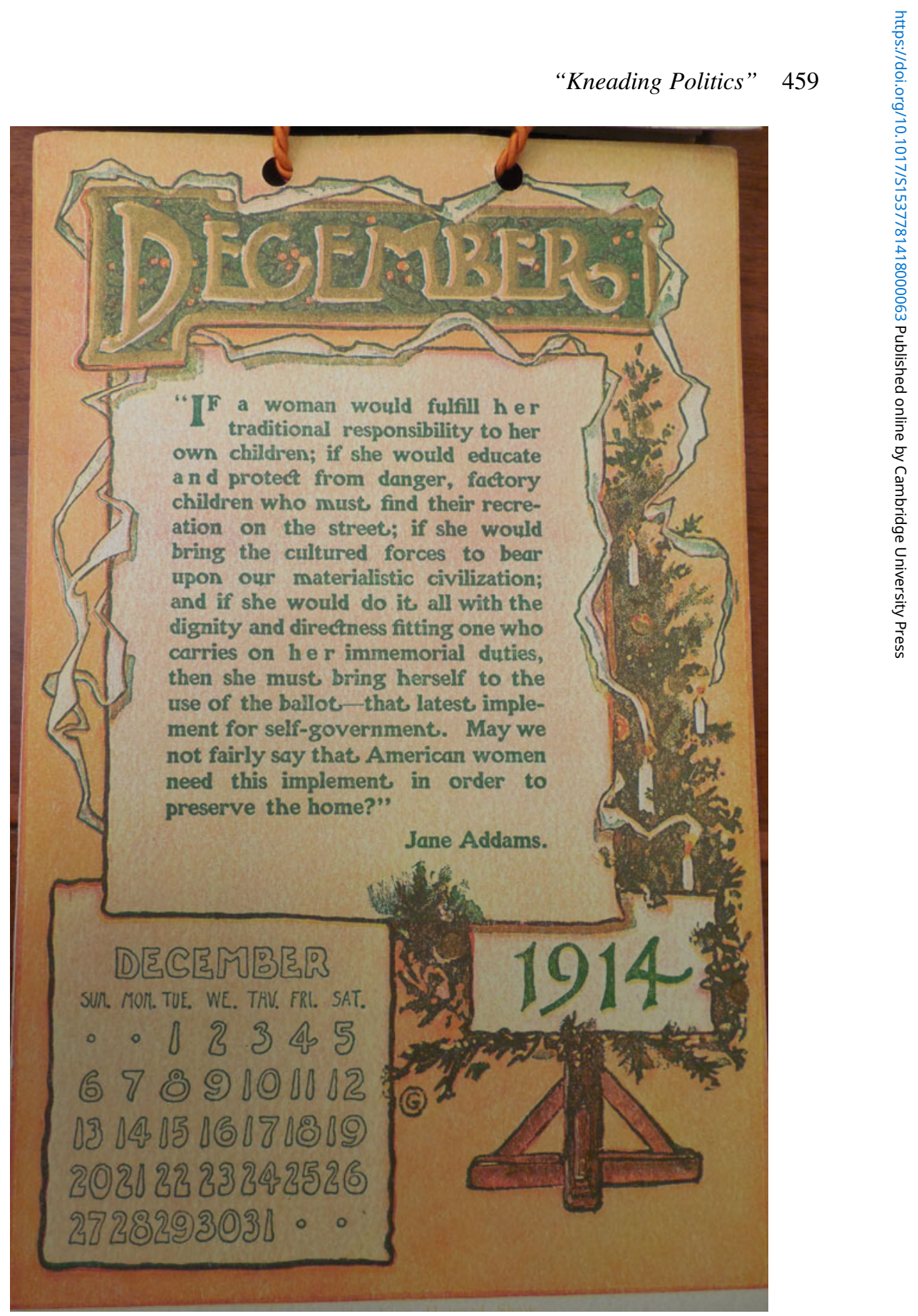

FIGURE 1. Anna Howard Shaw, "Votes for Women Ryte-Me Postcard Calendar: Containing Twelve Reasons Why Women Should Have the Right to Vote and Twelve Ryte-Me Post Cards" (Stewart Publishing Company, 1914), Susan B. Anthony Ephemera Collection, box 11, Huntington Library. This calendar reproduced suffrage articles and pamphlets that drew explicit connections between food, the home, and female enfranchisement. 
members of the women's clubs of the nation could vote, it would not be to [sic] difficult to secure pure food and drug legislation." 80 Throughout the first decades of the twentieth century, suffragists highlighted the connections between their movement and pure food; suffrage bazaars included "pure food talks" and "pure food exhibits" that encouraged onlookers to witness that suffragist "home-makers" wanted to take their rightful place as "civic housekeepers." 81

The epitome of the suffrage politicization of food safety came with the campaign for pure milk in the 1910s. An icon within this campaign, the illustration of a chubby, doeeyed baby graced suffrage postcards in 1912. Below a proclamation of "Votes for Mothers," a quote from Charlotte Perkins Gillman read: "Politics governs even the purity of the milk supply. It is not outside the home but inside the baby" (see Figure 2). ${ }^{82}$ In a private letter, California suffragist Alice Park explained the success of this slogan and encouraged other suffragists to reproduce it: "This picture and quotation were used on a poster in our campaign. I make up the plan, and my daughter Harriet drew the original baby. But I always wanted a window card-and wanted to place it in barber shops - because men — a procession of men go there — and have to wait—and can talk." ${ }^{33}$ Emphasizing their inability to directly influence pure food legislation, suffragists argued women could only safeguard vulnerable children with the vote. ${ }^{84}$ Mrs. Donald R. Hooker, for example, urged readers to consider "the infant in arms": "Men and not women legislate as to the quality of milk the babies may drink, and the result is that in Baltimore every summer between 700 and 800 infants die as a result of impure milk." If society allowed women to do their "natural business," she argued, then they would oversee the quality of the milk supply with the support of the ballot. ${ }^{85}$ Newspapers were receptive to these expediency arguments that did not focus on equal rights rhetoric. A 1913 article complimented the suffrage pure milk campaign, calling it a "mildly

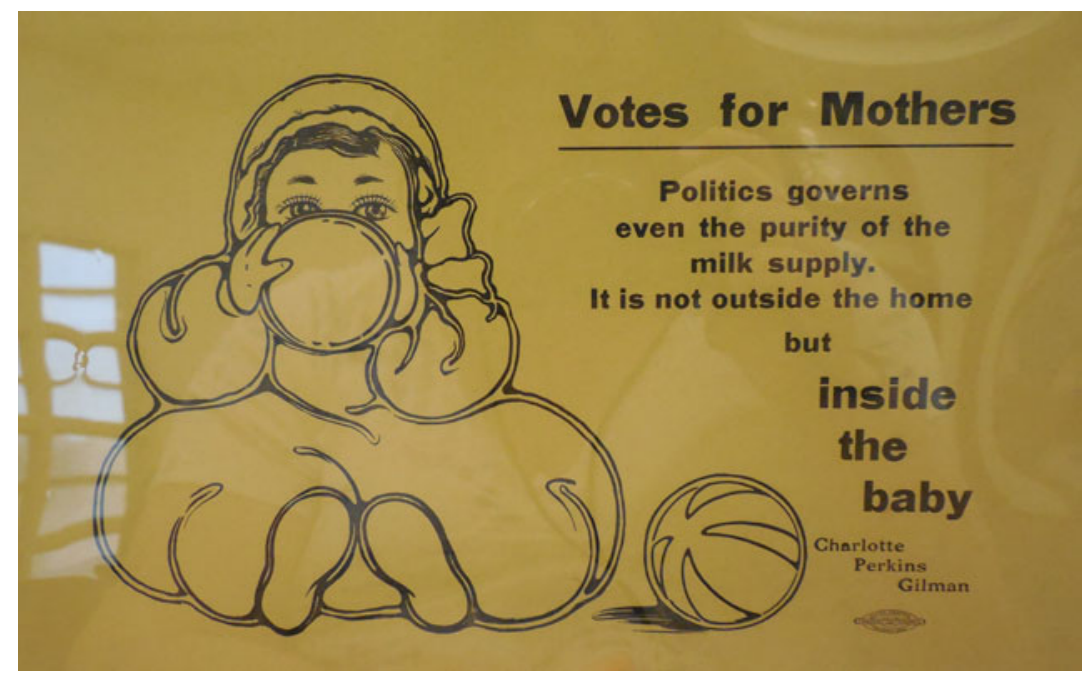

FIGURE 2. Votes for Mothers (October 1912), Susan B. Anthony Ephemera Collection, box 13, Huntington Library. 
argumentative device" with a "pacific tenor of appeal." The impressed author applauded suffrage parade banners addressing babies and pure milk because they resulted in a "friendly reception" with "little jeering" or "disorder." 86

Along with grounding these arguments in dominant gender expectations surrounding femininity, domesticity, and motherhood, suffragists intentionally capitalized on popular discussions about nutrition and food safety to promote their movement. In a 1907 article in the suffrage newspaper The Yellow Ribbon, suffragist Molly Warren outlined all of the cities and states around the nation considering laws related to the milk supply. Warren maintained that the political debates about milk safety effectively proved the need for women to carry their housekeeping skills "into public dealings, making officials feel that she is watching how they handle food supplies." The ballot was absolutely necessary, she argued, because "moral suasion, accompanied by a vote in the husband's name only, avails little." 87 Whereas home economists and municipal housekeepers avoided contentious politics, suffragists directly stated that women needed more than female moral influence. Women must have the vote. Suffragists reinforced this argument by highlighting how enfranchised women in the western states found their "united influence" for measures related to pure food and sanitation "more powerful because it has votes behind it." 88 Although disenfranchised women throughout the nation worked to improve the milk supply, they did so "under far greater difficulties." 99

\section{REPAIRING THE SUFFRAGE IMAGE}

At the turn of the twentieth century, suffragists confronted a feverish public debate about whether the ballot would not only change women in fundamental and irreversible ways, but also whether voting would destabilize the home. An editorial in The Washington Herald in 1910 conceded the necessity of women's enfranchisement if it came down to "justice between man and woman." Admitting that the movement "may be brave and idealistic," the authors nonetheless concluded that suffrage and womanhood were incompatible. In fact, women could best "make the world a happier and sweeter place" by focusing on homemaking, on "being a companion to her husband, a tender and loving mother to her children, a good housewife." 90 And in a 1908 survey of "leading men," Representative Cordell Hull of Tennessee declared suffrage a "wicked imposition" because the "destiny of this Republic" depends on "typical American homes, presided over by womanly women." 91 For opponents, suffragists threatened this model of the home and nation when they demanded electoral rights because extending the ballot challenged the social hierarchy of the sexes in which men politically represented women. Thus many warned that if women no longer depended on men for political representation, then marriage, children, and the home would be jeopardized as well. Although criticisms of the suffrage movement began in the previous century, they increased in the twentieth century with what one historian calls a "multimedia barrage of criticism unknown to their predecessors." 92 Suffragists capitalized on the popularity of scientific cooking, home economics, and municipal housekeeping to repair their image; their cookbooks and recipes demonstrated their personal and sincere commitment to domesticity, nutritious and safe foods, and an inviting home life.

Suffrage cookbooks served multiple purposes - they raised funds to cover the costs of campaigns, advertised the movement, and refuted antisuffrage claims that women's 
rights advocates abandoned their kitchens, homes, and families. Local suffrage organizations often printed and sold cookbooks to supplement the cost of running state and national campaigns; some of these fundraising efforts were unsuccessful, despite suffragists insisting that the success of their movement depended upon selling memorabilia. ${ }^{93}$ Suffragists also created cookbooks to capitalize on skills they already possessed. A pamphlet on fundraising from the National Woman Suffrage Publishing Company, for instance, urged local suffrage organizations to consider the skills of their active members and turn their "specialty into money" by baking, pickling, and sewing. ${ }^{94}$ Suffrage cookbooks, in particular, arose from a wave of community cookbooks that women's organizations compiled in the late nineteenth and early twentieth centuries as one of the most profitable forms of female charity work. ${ }^{95}$ Suffrage cookbooks followed patterns seen in community cookbooks as they expressed the dual purpose of supporting their cause and sharing delicious recipes, attested to the reliability of their instructions, and incorporated household tips. Suffrage cookbooks also followed two of the key plots that English scholar Annie Bower found in community cookbooks: with the integration plot, suffragists emphasized "social acceptance and achievement," telling a "story of the authors achieving assimilation through their acceptance of the larger society's conventions and standards"; simultaneously, suffragists used the differentiation plot wherein "the communal authors define themselves in some way different from other women," but they "never position themselves as rejected by the larger society." 96 With these integration and differentiation plots, women both reinscribed and resisted domestic gender ideology through the gendered medium of cookbooks. ${ }^{97}$ Thus, although community cookbooks celebrated the private sphere, they could also "rebuke a social order that devalues women's work." 98 Furthermore, as folklore scholar Janet Theophano argues, cookbooks often disguised "social disruption" with "unassuming rhetorical strategies." 99 Suffragists therefore created cookbooks to share recipes, raise money, and advance their political arguments; readers who followed the recipes could personally experience the success of suffrage cookery, the truth of suffragists' domesticity, and, perhaps, a conversion to the cause. After all, as a Florida newspaper exclaimed in 1917, those who "eat one or more of the dishes cooked according to these directions" will remember "good cooks not only want, but need and deserve good votes." 100 And by attacking the "age-old channel of the stomach," a California paper declared, these cookbooks proved to men that "a woman need not lose interest in cookery because she is a suffragist." 101 Suffrage cookbooks also strove to reach new audiences by adopting a literary form familiar to many women. The Woman's Journal praised suffrage cookery texts for placing suffrage propaganda in the hands of "those women who think they have "all the rights they want," the women who "will read a cook-book when she will not read anything else."102

Cookbooks offered suffragists a feminine and nonthreatening way to promote their beliefs. In evaluating the 1912 election in Kansas, Ida Husted Harper, a prolific suffrage writer, promised the New York Times that the "clean and honest" suffrage campaign used "methods dignified and womanly, [with] no 'militancy,' and no lawbreaking." They used the right methods, Harper argued, by "talking things over" with "their men," canvassing house to house, hosting fairs and suppers, and publishing a cookbook. ${ }^{103}$ The foreword of the New York pamphlet on Votes for Preparedness in the Home similarly promised, in the form of a poem, that “we don't inveigh with noisy din/ Nor loudly gerrymander;/ We 
only say, while cooking goose—/ 'This is the proper gander."'104 Some politicians and newspapers recognized suffrage cookery texts as a form of political maneuvering: opponents labeled the Washington cookbook a "political trick." 105 Emma Smith DeVoe, a leading activist in the Northwest, argued that these men misjudged suffragists' motives: "It's a very good cook book. We made it all ourselves. It embodies the best efforts of some of the best cooks in the State of Washington."106

As earnestly as suffragists claimed that cookbooks embodied their dedication to the home and their sincere interest in cookery, they also designed cookbooks as subtle political texts. DeVoe, for instance, avoided any radical techniques and embraced femininity because she believed it the best way to win allies in the West. DeVoe described the Washington cookbook as nonpolitical; however, she also acknowledged it was a "vindication of the slur" that suffragists lacked domestic traits. ${ }^{107}$ Although seemingly contradictory, this approach allowed activists to advertise their cause and counter negative stereotypes while avoiding the taint of radicalism. While some newspapers criticized this "trickery," others praised DeVoe as "motherly looking" and "nonmilitant" and complimented the cookbook as evidence of the "subtileness [sic] of the campaign" that appealed to man's stomach. ${ }^{108}$ As a refutation of "that favorite argument of the 'antis' that suffrage is likely to masculinize women," the cookbook promised to revive the image of activists as domestic loving creatures by providing "recipes equally good for attracting the mind and the appetite." 109 As one creative tool suffragists used to raise money and promote their movement, cookbooks created positive stereotypes through womanly, "nonpolitical," nonradical means.

Newspapers eagerly and favorably reported on the publication of suffrage cookbooks, and they even recognized their ability to dispel gendered antisuffrage claims. In an article reprinted in the Woman's Journal, the staff of the Record complimented those "wise sisters" for giving the suffrage cause a "mighty impetus" by waging a "skilful [sic] assault" on the "unyielding will of legislators or ordinary voters" through a "conquest by cook-book." Weeks away from its final publication, these writers expressed confidence that the suffrage cookbook could "turn more than one vote." With humor and apparent sincerity, the Record imagined politicians converted with a celery salad, lawmakers seized with a "persuasive dish," and antisuffragists overtaken by "vote-compelling refreshments." 110 This suffrage cooking manual, The Woman Suffrage Cook Book, compiled in Boston by Hattie A. Burr, first published in 1886 and reprinted in 1890, aimed to fulfill an "important mission." In addition to serving as a "practical, reliable authority on cookery, housekeeping, and care of the sick," Burr intended the text be "an advocate for the elevation and enfranchisement of woman." 111 The Record, now with cookbook in hand, declared it a "potent missionary" sure to "convict and convert." 112

Newspapers praised The Woman Suffrage Cook Book, in part, because it included the names and recipes of actual suffragists from around the nation. The Record testified that "alarmists of both sexes" declared suffrage and domesticity utterly incompatible. The cookbook, however, would be "a confession book, a proof that, even if they wish to vote, the suffragists cherish a feminine interest in culinary matters." 113 With over one hundred and fifty names, the list of contributors attested to a nationwide base of suffrage supporters capable of crafting a meal: many lived within the Northeast but a significant number sent savory instructions from as far away as Iowa, Nebraska, Oregon, Illinois, 
Kansas, Texas, Montana, and London. Burr removed the abstraction of suffragists as cooks by attributing each recipe to its creator: readers could now associate Alice Stone Blackwell with scalloped onions, Matilda Josyln Gage with baked tomatoes, Clara Berwick Colby with grape jelly, and Lucy Stone with homemade yeast. ${ }^{114}$

Suffrage cookbook editors around the country linked specific activists to domesticity by attributing recipes to individual women, thereby garnering favorable press coverage. Although it took on different forms, suffragists frequently identified contributors in suffrage cookery texts: both the full-length work from Detroit and a New York pamphlet provided attribution; the cookbooks from the Clinton Political Equality Club and Wimodaughsis linked each recipe with its contributor; a small book created for a 1915 NAWSA convention contained recipes from female voters in California who continued to cook; and a baking pamphlet from New York titled each recipe after a famous activist (from "Aunt Susan Marble Cake" to "Lucy Stone Boston Brown Bread"). ${ }^{115}$ Author attribution in suffrage cookbooks mirrored community cookbooks; an editor penned an introduction on behalf of the organization, outlined the goals of the cookbook, and then attributed individual recipes to the specific members of the community who supplied them. So while the editor introduced the text and its purpose, by attributing the recipes to their creators, she reminded the "reader that individual women have used, adjusted, and served these dishes." 116 Similar to Burr, The Suffrage Cookbook, edited by L. O. Kleber, included a list of national contributors from Alabama to Wyoming, California, Virginia, Kentucky, and Arizona. ${ }^{117}$ Endorsed by the Woman's Journal as "in itself an argument for the cause," the cookbook attracted praise because it highlighted prominent contributors. In fact, the Woman's Journal argued that Kleber's cookbook "ought to silence forever the slander that women who want to vote do not know how to cook." 118 The popular press also took notice of specific dishes signed by their suffragist creators. The New York Tribune, for instance, observed, "There is scarcely a suffragist of note in the country who isn't represented in this pretty blue bound book." The article pointed to the "fine breads" that were the "proudest achievement" of Medill McCormick and the "pain d'oeufs" that Carrie Chapman Catt made, "her friends say, with all the skill with which she delivers a suffrage speech." 119 The Milwaukee Leader also published a collection of suffrage recipes in 1912 under the headline: "Will Suffragists Neglect Home? Try These Recipes, Then Judge." ${ }^{20}$ Suffragists meant these recipes to demonstrate their commitment to domesticity and love for and skill with a particular dish. Any reader who doubted that "womanly" suffragists possessed "feminine virtues" simply needed to turn to their recipes and "see your error." 121

Suffrage cookbooks also used the formula of a recipe to introduce humor, address political issues, and critique opponents. "Anti's Favorite Hash," in The Suffrage Cookbook (1915), for example, called for "1 lb. truth thoroughly mangled/ 1 generous handful of injustice/ (Sprinkle over everything in the pan)/ 1 tumbler acetic acid (well shaken)." The recipe suggested, "a little vitriol will add a delightful tang and a string of nonsense should be dropped in at the last as if by accident." 122 Along with criticizing antisuffragists, the cookbook provided a recipe on how to convert the hesitant by baking the perfect "Pie for a Suffragist's Doubting Husband." The primary ingredients included civic and social issues women could improve with the vote: " 1 qt. human kindness/ 8 reasons:/ War/ White Slavery/ Child Labor/ 8,000,000 Working Women/ Bad Roads/ Poisonous Water/ Impure Food." Most importantly, "mix the crust with tact 
and velvet gloves, using no sarcasm, especially with the upper crust [which must be] handled with extreme care for they sour quickly if manipulated roughly." ${ }^{123}$ Like countless suffrage pamphlets, books, articles, and speeches, these recipes addressed issues central to the debate over woman's suffrage but did so in a fanciful and humorous way. Suffragists' recipes imbedded deeply political issues in a form and context that used domesticity and cookery as metaphors for political engagement. Thus, even if equality seemed a "queer subject for a cook-book," activists hybridized cookery instructions with political tracts to appeal to a wider audience. ${ }^{124}$

Suffragists most directly and literally displayed their commitment to food, domestic science, and the home through practical demonstrations that fed their audiences. From the early nineteenth through the turn of the twentieth centuries, women's organizations around the country hosted fundraising fairs to benefit a variety of causes. These women's fairs simultaneously reinforced and undercut expectations of domesticity by combining the sale of food and home goods with the business, marketing, publicity, and bookkeeping skills necessary for running such large events. ${ }^{125}$ The political purpose of suffrage bazaars, women's studies scholar Beverly Gordon argues, "was certainly evident" as banners and booths advertised that the fairs raised funds for suffrage organizations. ${ }^{126}$ Journalists noted this décor, focusing on how "tastefully decorated" bazaars offered consumers a variety of "fancy articles." 127 This type of positive press coverage played into suffrage tactics by promoting the domesticity and visibility of the movement without stressing divisive elements of the suffrage debate. A NAWSA handbook on "Organizing to Win," published in the 1910s, emphasized the need for such events to appeal to those skeptical of the movement: "All our technical, political and legislative work will profit us little unless we are at the same time preparing the minds of the people for this great reform." Workers and committees must "devise a thousand ways of appealing locally and generally to the heart and mind of the unconvinced, and of getting the message of equal suffrage to those who would never come to us in a regular suffrage meeting." Along with booths at pure food and domestic science exhibits, the instructional pamphlet recommended setting up suffrage lunch wagons (see Figure 3). Such "unusual demonstrations," as long as they were "dignified, gracious, tactful and earnest," would bring the "truth of democracy" to new audiences. ${ }^{128}$ With this advice listed under the "propaganda" section of the handbook, suffragists were well aware that food was a channel for converting Americans to their cause.

Thus, in venues throughout the country, suffragists delivered "suffrage food for minds that need coaxing" at bake sales, food markets, and Saturday fairs. ${ }^{129}$ Newspapers described suffrage bake sales and food carts, laden with cakes and gingerbread "daintily iced and decorated," as evidence of "what good housewives they are." 130 When breads, doughnuts, pies, and cakes sold out within an hour, the Oneonta Star reported, "the suffragists can cook." 131 By successfully hosting dinners, Minnesota suffrage associations bore "witness to the fact that no cooking can excel suffrage cooking." 132 While the Indianapolis News predicted, "Husbands will soon be admonishing their wives to make bread like the suffragists make."133 Activists in Atlanta, Georgia, impressed local diners when they opened a suffrage café to host a Shriner convention. For the café they promised "suffrage-made soup and suffrage-made salads, sandwiches, ice cream and cakes," "dainty morsels and substantial meals that will 


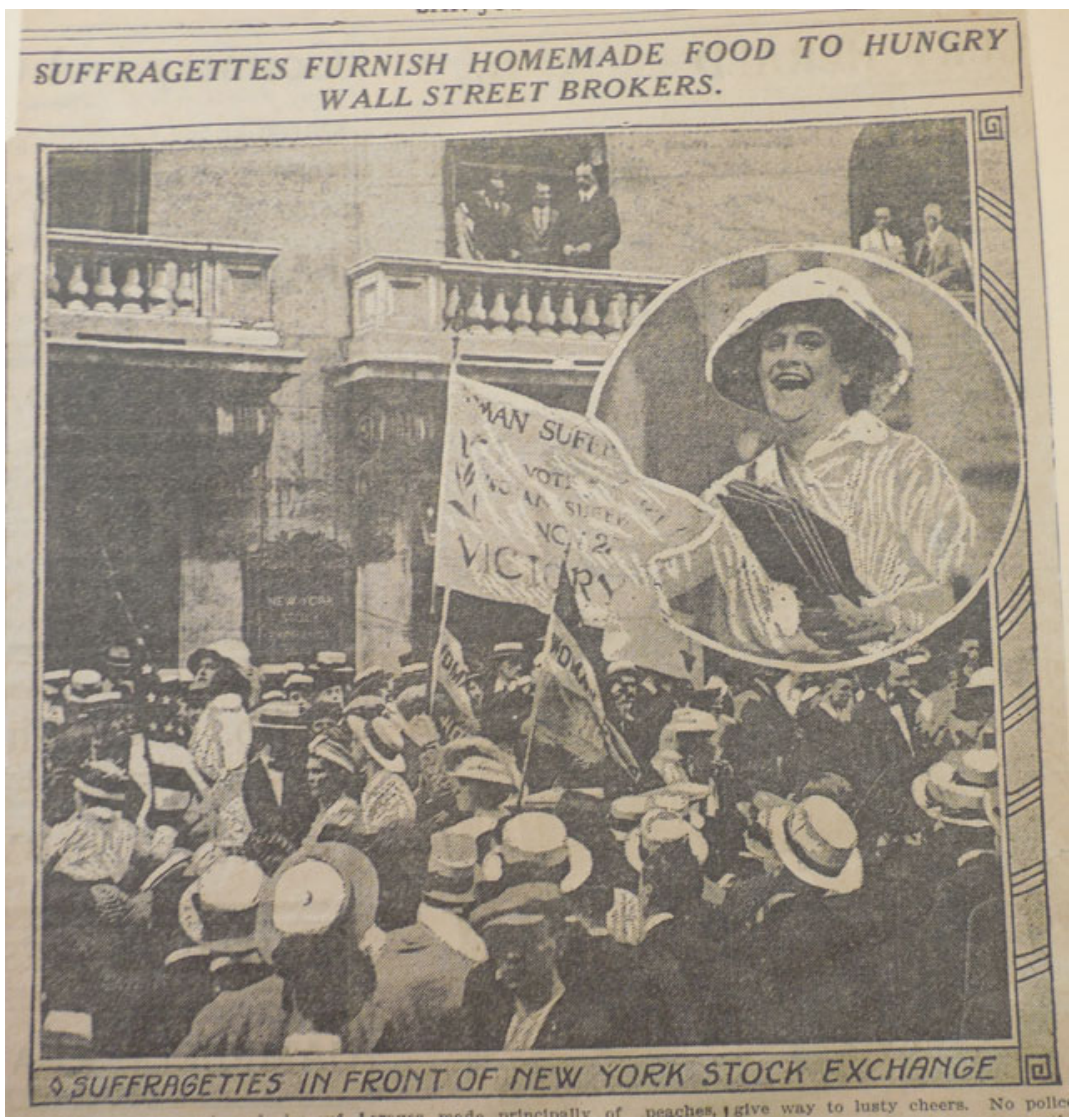

FIGURE 3. "Suffragettes Furnish Homemade Food to Hungry Wall Street Brokers," San Jose Mercury Herald, 1915, Susan B. Anthony Ephemera Collection, clippings, volume 16, Huntington Library. Suffragists in 1915 made headlines for furnishing "Homemade Food to Hungry Wall Street Brokers." Operating out of a restaurant and multiple lunch wagons, "suffrage sundaes, cooling beverages made principally of peaches, were handed right and left" and "the suffrage dainties vanished almost immediately." The food "caused such a stir among the brokers that Wall street was alive from 11 o'clock till 5 with animated capitalists." Men not only followed their stomachs to the lunch wagons, they also crowded the tables and spilled into the street listening to suffrage speakers.

rival even the meals that 'mother used to make."' By dividing up the menu and competing to create better dishes, the women of the Atlanta Equal Suffrage Association refuted "the argument of the antis that women who seek the ballot are remiss as housekeepers and as cooks." 134 Suffragists emphasized dainty dishes, suffrage savories, and mothers cooking and intentionally played into gender expectations that said women possessed an inherent interest and skill in crafting comforting meals. Suffragists' embrace of domesticity, however, was not accidental or ruinous to their cause. By entering public spaces with practical demonstrations of their cooking in hand, suffragists proved their compliance with gender expectations and, at the same time, insisted on their right to the franchise. 
In November 1912, The Woman's Journal printed a "pretty story" from Michigan that had "the advantage of being true." The president of the local Equal Suffrage Association unexpectedly took charge of the woman suffrage booth at the local fair. Although unprepared for this responsibility, she stood "equal to the emergency, she baked her bread, took all the children with her, decorated the booth, looked after the children, entered her bread as 'Suffrage Bread,' and took first prize for it." As the perfect example of the ideal suffragist, The Woman's Journal announced, "This Woman Can Cook, Tend Children and Work for [the] Ballot, All at Once." 135 More than a bakery submission at a local fair, this anecdote represents a larger dialogue about the compatibility of women, political rights, and domesticity.

Large-scale social and cultural changes in the late nineteenth and early twentieth centuries drove the American public into a debate about the role of the sexes: as women increasingly entered colleges and the professions, the woman suffrage movement further propelled arguments about the capacities of women. Antisuffragists capitalized on anxieties about the role of women by claiming that masculine, unsexed suffragists wished to abandon the home and family. Scholars note that with such claims "anti-suffrage women articulated cultural values that were perfectly in keeping with this nation's traditions." By claiming the importance of the home and denouncing women who stepped beyond the private realm, "antis put into words what society had believed for a long time and had practiced for generations." 136 The dichotomy between suffragist and antisuffragist becomes less clear, in this regard, when scrutinizing how female suffragists responded to gendered charges. In adopting cookery rhetoric between the 1880s and the 1910s, suffragists began to speak the same cultural language as antisuffragists: they connected women with domesticity and socially acceptable forms of womanhood.

Over four decades, suffragists utilized food in a number of ways, capitalizing on trends in popular culture, science, and national politics to promote votes for women. During the era that historians categorize as the doldrums, suffragists began to connect their cause to scientific cooking. The home economics emphasis on modernization, rationality, and the elevation of women's work dovetailed with suffragists' concerns about the public and private status of women. Unlike many food reformers at the turn of the century, however, suffragists intentionally politicized food. They did so, specifically, by using municipal housekeeping arguments to insist that women needed to use their domestic skills and expertise to improve both private and public conditions-from garbage removal and sanitation, to clean air and safe parks, to the quality and safety of food. More than informed citizens, suffragists argued women needed the franchise as wives and mothers to care for their families. By the turn of the century, suffragists around the country strategically countered antisuffrage claims with cookery rhetoric. By hosting bake sales, opening lunch carts, and organizing bazaars, suffragists put their domesticity and culinary capabilities on display for the hungry public. Although recipes for "spaghetti a la suffragette" and lunch wagons with "suffrage sundaes" used humor and whimsy to garner attention, suffragists remained focused on their goal-votes for women. By hosting bake sales, printing cookbooks, and sharing recipes, suffragists did not mistakenly embrace the trappings of domesticity. Rather, they recognized an argument consistently used against their cause and responded by constructing a new, and more socially acceptable, image of their movement. 


\section{NOTES}

I am incredibly grateful for the personal and scholarly community that helped me brainstorm, research, write, and edit this work, especially: Natona Derleth, Katie Stankiewicz, Leigh Ann Wheeler, Julia B. Devin, Tiffany Baugh-Helton, and Richard Mackenney. A Helen L. Bing Fellowship at the Huntington Library made much of this research possible, and Kenneth Florey's immense generosity granted me access to rare sources in his private collection. I also received invaluable feedback on an earlier version of this article at the annual meeting of the Western Association of Women Historians where this research received the Carol Gold Graduate Student Conference Paper Prize. Finally, I would like to thank the editors, staff, and reviewers at the Journal of the Gilded Age and Progressive Era for their incisive feedback and generous guidance.

1'M'Grane, Like Rupp, Sick of Suffragism: Cooks and Does the Housework, but Can't Stand His Wife's Speech Rehearsals," The New York Times, Aug. 28, 1913.

2“'Hubby's Demand for Supper Stops Suffrage Speech: Angry Wife Has Him Arrested When He Orders Her Home," The Daily Telegraph and Daily Witness (Montreal), Aug. 11, 1913, 7.

3"Rupp Not Needed at Rupp Suppers: Mrs. Rupp Makes That Plain to Reporter as She Cooks for the Children," The New York Times, Aug. 9, 1913. Some newspapers, such as The New York Times, refer to "Martha" Rupp though many simply use "Mrs. Rupp." I have chosen to use the most commonly used first name, "Maria."

4"Home Is Place for Suffragists, They Say," The Toledo News-Bee (Cincinnati, OH), Aug. 9, 1913, 10.

5"Meals and Suffragettes: Rupp, of Dinnerless Fame, Upholds a Vital Domestic Principle," San Francisco Chronicle, Aug. 28, 1913, 6. Also see, for example: "Suffragist Wife Wins: Husband Who Interrupted Oration Found Guilty by Magistrate," The Washington Post, Aug. 15, 1913, 6; "Rupp Gets His Supper, But In Police Station: Hungry Man Breaks Up His Wife's Suffrage Meeting: She Causes His Arrest," The Indianapolis News, Aug. 8, 1913, 1; "This Is Pretty Far to Go for Votes: Suffragist Fails to Get Spouse's Supper and Jails Him When He Objects," The Inter Ocean (Chicago), Aug. 8, 1913, 1; "Suffragettes Praise Act of Magistrate," The Scranton Republican, Aug. 11, 1913, 5; "Rupp, The Militant Husband," Lincoln Evening Journal, Apr. 1, 1914, 7.

${ }^{6}$ Linda K. Kerber, "Separate Spheres, Female Worlds, Woman's Place: The Rhetoric of Women's History," The Journal of American History 75:1 (1988): 21. For recent histories that complicate "separate spheres" see Sarah Deutsch, Women and the City: Gender, Space, and Power in Boston, 1870-1940 (New York: Oxford University Press, 2000); Nan Enstad, Ladies of Labor, Girls of Adventure: Working Women, Popular Culture, and Labor Politics at the Turn of the Twentieth Century (New York: Columbia University Press, 1999). I agree with Robert O. Self who argues that even though gender norms did not represent how most Americans actually lived, "the conflict over this political and ideological fiction was very real." Robert O. Self, All in the Family: The Realignment of American Democracy Since the 1960s (New York: Hill and Wang, 2012), 5.

${ }^{7}$ Linda K. Kerber, Women of the Republic: Intellect and Ideology in Revolutionary America (Chapel Hill: University of North Carolina Press, 1980), 235-37, 269-88; Kerber, "Separate Spheres," 20; Paula Baker, "The Domestication of Politics: Women and American Political Society, 1780-1920," The American Historical Review 89:3 (1984): 621.

${ }^{8}$ William A. Hammond, "Women in Politics," The North American Review 137:321 (Aug. 1883): 137-38.

${ }^{9}$ Elna C. Green, Southern Strategies: Southern Women and the Woman Suffrage Question (Chapel Hill: University of North Carolina Press, 1997), 57.

${ }^{10}$ Aileen S. Kraditor, The Ideas of the Woman Suffrage Movement, 1890-1920 (New York: Columbia University Press, 1965), 52-78.

${ }^{11}$ Louise M. Newman, "Reflections on Aileen Kraditor's Legacy: Fifty Years of Woman Suffrage Historiography, 1965-2014," The Journal of the Gilded Age and Progressive Era 14:3 (2015): 294.

${ }^{12}$ Steven M. Buechler, Women's Movements in the United States: Woman Suffrage, Equal Rights, and Beyond (New Brunswick, NJ: Rutgers University Press, 1990), 92; Newman, "Reflections on Aileen Kraditor's Legacy," 294-97, 307. Sarah Hunter Graham rejects the "justice versus expediency argument" as a "misreading" because Kraditor "maintains that although expedient arguments for the vote appeared around the turn of the century and increased in number as the suffrage campaign progressed, the justice argument continued to be employed by suffragists until their victory in 1920." Sara Hunter Graham, Woman Suffrage and the New Democracy (New Haven, CT: Yale University Press, 1996), 172.

${ }^{13}$ Graham, Woman Suffrage and the New Democracy, 30.

${ }^{14}$ Buechler, Women's Movements, 93, 92, 98. 
${ }^{15}$ Leila R. Brammer, Excluded from Suffrage History: Matilda Josyln Gage, Nineteenth Century American Feminist (Westport, CT: Greenwood Press, 2000), 93-96; Grace Farrell, "Beneath the Suffrage Narrative," Canadian Review of American Studies 36:1 (2006): 52. This also meant focusing on suffrage and ignoring larger woman's issues that might distract from the issue of enfranchisement. Jennifer Ross-Nazzal, Winning the West for Women: The Life of Suffragist Emma Smith DeVoe (Seattle: University of Washington Press, 2015), 38.

${ }^{16}$ Ross-Nazzal, Winning the West, 36.

${ }^{17}$ Holly J. McCammon and Karen Campbell, "Winning the Vote in the West: The Political Successes of the Women's Suffrage Movements, 1866-1919," Gender and Society 15:1 (2001): 74. Also see Suzanne Marilley, Woman Suffrage and the Origins of Liberal Feminism in the United States, 1820-1910 (Cambridge, MA: Harvard University Press, 1996), 8.

${ }^{18}$ First popularized by Eleanor Flexner, Century of Struggle: The Woman's Rights Movement in the United States (Cambridge, MA: Belknap Press of Harvard University Press, 1975); Margaret Finnegan, Selling Suffrage: Consumer Culture \& Votes for Women (New York: Columbia University Press, 1999), 7; Faye E. Dudden, Fighting Chance: The Struggle over Woman Suffrage and Black Suffrage in Reconstruction America (New York: Oxford University Press, 2011), 197; Holly McCammon, "Out of the Parlors and into the Streets: The Changing Tactical Repertoire of the U.S. Women's Suffrage Movements," Social Forces 81:3 (Mar. 2003): 791; Trisha Franzen, "Singular Leadership: Anna Howard Shaw, Single Women and the US Woman Suffrage Movement," Women's History Review 17:3 (July 2008): 423; Jean H. Baker, Votes for Women: The Struggle for Suffrage Revisited (New York: Oxford University Press, 2002); Rebecca Edwards, "Pioneers at the Polls" in Votes for Women: The Struggle for Suffrage Revisited, ed. Jean Baker (New York: Oxford University Press, 2002), 98.

${ }^{19}$ Graham, Woman Suffrage and the New Democracy, 33-52.

${ }^{20}$ For brief mentions of cookbooks see Green, Southern Strategies, 58; Marjorie Spruill Wheeler, New Women of the New South: The Leaders of the Woman Suffrage Movement in the Southern States (New York: Oxford University Press, 1993), 75; Rebecca J. Mead, How the Vote Was Won: Woman Suffrage in the Western United States, 1868-1914 (New York: New York University Press, 2004), 112; John C. Putman, Class and Gender Politics in Progressive-Era Seattle (Reno: University of Nevada Press, 2008), 107; Mary Chapman and Angela Mills, eds., Treacherous Texts: U.S. Suffrage Literature, 1846-1946 (New Brunswick, NJ: Rutgers University Press, 2011), 172. The most focused study of suffrage cookbooks is an unpublished master's thesis (although it is not comprehensive as it only discusses three cookbooks): Sarah C. Watts, "Recipes for Radical Change: The Use of Cookbooks in the American Woman Suffrage Movement" (Master's thesis, Trinity College, 2008).

${ }^{21}$ Finnegan, Selling Suffrage, 117-18.

${ }^{22}$ Brammer, Excluded from Suffrage History, 105.

${ }^{23}$ Sherrie A. Inness, "Introduction: Thinking Food/Thinking Gender" in Kitchen Culture in America: Popular Representations of Food, Gender, and Race, ed. Sherrie A Inness (Philadelphia: University of Pennsylvania Press, 2001), 3-12.

${ }^{24}$ Newman, "Reflections on Aileen Kraditor's Legacy"; Louise Newman, White Women's Rights: The Racial Origins of Feminism in the United States (New York: Oxford University Press, 2010), 8, 34; Gail Bederman, Manliness and Civilization: A Cultural History of Race in the United States, 1880-1917 (Chicago: University of Chicago Press, 1995), 25.

${ }^{25}$ Helen Zoe Veit, Modern Food, Moral Food: Self-Control, Science, and the Rise of Modern American Eating in the Early Twentieth Century (Chapel Hill: University of North Carolina Press, 2013), 103-7.

${ }^{26}$ Courtney Irene Powell Thomas, In Food We Trust: The Politics of Purity in American Food Regulation (Lincoln: University of Nebraska Press, 2014), 41.

${ }^{27}$ Thomas, In Food We Trust, 46-48; Megan J. Elias, Food in the United States, 1890-1945 (Santa Barbara, CA: Greenwood Press, 2009), 6.

${ }^{28}$ Megan J. Elias, Stir It Up: Home Economics in American Culture (Philadelphia: University of Pennsylvania Press, 2008), 6; Harvey Levenstein, Revolution at the Table: The Transformation of the American Diet (New York: Oxford University Press, 1988), 18-19.

${ }^{29}$ Elias, Food in the United States, 45.

${ }^{30}$ Elias, Stir It Up, 22; Levenstein, Revolution, 44-55; Adam D. Shprintzen, The Vegetarian Crusade: The Rise of an American Reform Movement, 1817-1921 (Chapel Hill: University of North Carolina Press, 2013), 115-16. 
${ }^{31}$ Carol Fisher, The American Cookbook: A History (Jefferson, NC: McFarland, 2006), 18, 28; Elias, Stir, 5.

${ }^{32}$ Levenstein, Revolution, 60-61.

${ }^{33}$ Levenstein, Revolution, 59-62. While food reformers began championing dietary changes after the Civil War, they failed to gain widespread support from the "normative culture" because of their association with radical politics. Shprintzen, The Vegetarian Crusade, 5.

${ }^{34}$ Mary A. Livermore, "Kitchen Literature," The Woman's Journal 8:29 (July 21, 1877): 228; "That Celebrated 'Cook Book,"” The Woman's Tribune 5:11 (Feb. 18, 1888); D. A. Lincoln, "Cook Books by Mrs. D. A. Lincoln," The Woman's Journal 22:49 (Dec. 5, 1891): 2; "Healthful Cook-Book Wanted," The Woman's Journal 23:1 (Jan. 2, 1892): 2; Genevieve Tucker, M.D., "Sanitary and Economic Cooking," The Woman's Journal 23:3 (Jan. 16, 1892): 19; M. A. Black, "Healthful Cooking," The Woman's Journal 23:4 (Jan. 23, 1892): 28; "Book Reviews," The Woman's Tribune 11:2 (Jan. 13, 1894): 7.

${ }^{35}$ See, for example: "Household Sins," The Woman's Journal 1:34 (Aug. 27, 1870): 271; "Household Receipts," The Woman's Journal 2:40 (Oct. 7, 1871): 319; “Care of Fruit Cans," The Woman's Journal 8:12 (Mar. 24, 1877): 90; "How To Boil and Stew," The Woman's Journal 22:11 (May 29, 1880): 171; "Household Hints," The Woman's Tribune 2:3 (Jan. 1885): 2; “How to Make a Happy Home," The Woman's Journal 23:3 (Jan. 16, 1892): 24; Florence M. Adkinson, "Home Hints and Helps," The Woman's Column 37:10 (1897): 2; "How to Cook Without Coal," The Woman's Column 20:15 (1902): 3; "Healthful Cook-Book Wanted," The Woman's Journal 23:1 (Jan. 2, 1892): 2.

${ }^{36}$ See, for example, Livermore, "Kitchen Literature," 228; Lincoln, "Cook Books," 2.

${ }^{37}$ Elias, Stir It Up, 33.

${ }^{38}$ Hattie A. Burr, ed., The Woman Suffrage Cook Book: Containing Thoroughly Tested and Reliable Recipes for Cooking, Directions for the Care of the Sick, and Practical Suggestions, Contributed Especially for This Work (H. A. Burr, 1886 [second edition, 1890]), 4-6, 10, 32, 62, 98, 107-9, 121.

${ }^{39}$ Burr, Woman Suffrage Cookbook, 29-30, 37, 42-43, 47-48, 67-68. On how home economists suggested molding, containing, and structuring food into efficient and tidy forms, see Laura Shapiro, Perfection Salad: Women and Cooking at the Turn of the Century (New York: Farrar, Straus, and Giroux, 1986), 98-99.

${ }^{40}$ Burr, The Woman Suffrage Cook Book, 21, 25, 40, 52-54, 59, 63. For the emphasis home economists put on the importance of triggering appetite and salivation, see Shapiro, Perfection Salad, 81-84.

${ }^{41}$ Burr, The Woman Suffrage Cook Book, 122-24.

${ }^{42}$ Elias, Stir It Up, 7.

${ }^{43}$ Shapiro, Perfection Salad, 5. The movement began calling itself "home economics" in earnest after its first organized meeting in Lake Placid, New York, in 1899. This group called itself the Lake Placid Conference on Home Economics before changing its name to the American Home Economics Association in 1909. Elias, Stir It Up, 8; Shapiro, Perfection Salad, 7-8.

${ }^{44}$ Elias, Stir It Up, 1; Shapiro, Perfection Salad, 4.

${ }^{45}$ Shapiro, Perfection Salad, 4.

${ }^{46}$ Veit, Modern Food, Moral Food, 78-79.

${ }^{47}$ Shapiro, Perfection Salad, 7; Levenstein, Revolution, 85.

${ }^{48}$ Shapiro, Perfection Salad, 212; Levenstein, Revolution, 97.

${ }^{49}$ Elias, Stir It Up, 8; Shprintzen, The Vegetarian Crusade, 180.

${ }^{50}$ Marilley, Woman Suffrage and the Origins, 9; Anastatia Sims, "Beyond the Ballot: The Radical Vision of the Antisuffragists" in Votes for Women!: The Woman Suffrage Movement in Tennessee, the South, and the Nation, ed. Marjorie Spruill Wheeler (Knoxville: University of Tennessee Press, 1995), 106; Flexner, Century of Struggle, 294-305; Kraditor, The Ideas of the Woman Suffrage Movement, 14-42; Thomas Jablonsky, "Female Opposition: The Anti-Suffrage Campaign" in Votes for Women: The Struggle for Suffrage Revisited, ed. Jean Baker (New York: Oxford University Press, 2002), 127. A range of authors (between the 1850s and the 1910s) spoke out against suffrage as disruptive to the natural balance between the sexes, possibly harmful to the home, and risky to society.

51،Why Women Shouldn't Vote: A 1905 Speech,” Ukiah Daily Journal (California), Mar. 13, 2005, 3.

52، Advice to the Women: Female Suffrage Derided: Smart Iowa Editor Is In Hot Water Over His Quaint Views," The Macon Republican (Missouri), Nov. 25, 1905, 1.

53"Suffragette Savories," American Suffragette 1:12 (Aug. 1910): 15. For recipes in suffrage newspapers see, for example: "Original Recipes," The Woman's Journal 8:12 (Mar. 24, 1877): 90; "Before and After Meals," American Suffragette 1:2 (July 1909): 3; "Bisque of Tomato with Croutans [sic]," The American Suffragette 1:8 (Feb. 1910): 26; "Suffragette No-Meat Savories," American Suffragette 1:10 (May 1910): 23; 
"Suffragette Savories," American Suffragette 1:12 (Aug. 1910): 15; "Suffrage Savories," American Suffragette 2:2 (Oct. 1910): 22.

54“"Better Way to Prepare Food,” The Woman's Journal 28:52 (Dec. 25, 1897): 416; “Suffrage Notes,” The Inter Ocean (Chicago), Mar. 14, 1914, 4.

55"Woman Suffrage and the Home," Friends' Intelligencer 66:7 (Feb. 13, 1909): 108.

${ }^{56}$ Clinton Political Equality Club, Choice Recipes Compiled for the Busy Housewife 1916 (Clinton, NY: The Courier Press, 1916), 1-2, in the private collection of Dr. Kenneth Florey.

${ }^{57}$ Elias, Stir It Up, 12; Shapiro, Perfection Salad, 4.

${ }^{58}$ Shapiro, Perfection Salad, 190, 104.

${ }^{59}$ Elias, Stir It Up, 12; Shapiro, Perfection Salad, 45.

${ }^{60}$ For example, see Elizabeth Cady Stanton, Eighty Years and More: Reminiscences, 1815-1897 (New York: Schocken Books, 1971 [1898]), 136-47.

${ }^{61}$ Elizabeth Cady Stanton, Susan B. Anthony, and Matilda Josyln Gage, eds., History of Woman Suffrage, vol. 1, 1848-1861 (Rochester, NY: Susan B. Anthony, 1881), 1, 214, 657, 803, 910; Elizabeth Cady Stanton, Susan B. Anthony, and Matilda Josyln Gage, eds., History of Woman Suffrage, vol. 2, 1861-1876 (Rochester, NY: Susan B. Anthony, 1886), 854, 910; Elizabeth Cady Stanton, Susan B. Anthony, and Matilda Josyln Gage, eds., History of Woman Suffrage, vol. 3, 1876-1885 (Rochester, NY: Susan B. Anthony, 1886), 304, 743, 935; Susan B. Anthony and Ida Husted Harper, eds., History of Woman Suffrage, vol. 4, 1883-1900 (Rochester, NY: Susan B. Anthony, 1902), 306.

${ }^{62}$ Stanton, Anthony, and Gage, History of Woman Suffrage, 1:910.

${ }^{63}$ On home economists distancing themselves from politics, see Elias, Stir It Up, 9; Shapiro, Perfection Salad, 196-97.

${ }^{64}$ Specifically, Shapiro writes: "Of course they failed in their crusade, how could they not? They chose domesticity as a way of getting out of the house, and food as a means of transcending the body." Shapiro, Perfection Salad, 10.

${ }^{65}$ Kraditor, The Ideas of the Woman Suffrage Movement, 52; Paula Baker, "The Domestication of Politics: Women and American Political Society, 1780-1920" in Women, the State, and Welfare, ed. Linda Gordon (Madison: University of Wisconsin Press, 1990), 70-72.

${ }^{66}$ Suffragists and antisuffragists frequently identified similar social problems; see Thomas J. Jablonsky, The Home, Heaven, and Mother Party: Female Anti-Suffragists in the United States, 1868-1920 (Brooklyn, NY: Carlson, 1994), 126. For the connection between suffrage and municipal housekeeping see: Ross-Nazzal, Winning the West, 43; Buechler, Women's Movements, 100-101; Baker, "The Domestication of Politics," 55. ${ }^{67}$ Daphne Spain, How Women Saved the City (Minneapolis: University of Minnesota Press, 2001), 9.

${ }^{68}$ Amy Laurel Hobbs, “'The World, Our Home': The Rhetorical Vision of Women's Clubs in American Literature, 1870-1920" (PhD diss, University of Maryland, 2005), 24, 121-26; Spain, How Women Saved the City, 47, 179-81, 203-4, 9-10, 78-79.

${ }^{69}$ Carrie Chapman Catt, "The Home and the Government," The Yellow Ribbon (California) 1:6 (Mar. 1907): 4. Catt served as president of NAWSA from 1900 to 1904 and then again from 1915 to 1947.

${ }^{70}$ Anne O'Hagan, "Why the Housekeeper Needs the Vote" (New York: National Woman Suffrage Publishing Co., 19-?), 2. This article was reproduced in a suffrage calendar; see Anna Howard Shaw, "Votes for Women Ryte-Me Postcard Calendar: Containing Twelve Reasons Why Women Should Have the Right to Vote and Twelve Ryte-Me Post Cards" (Stewart Publishing Company, 1914), Susan B. Anthony Ephemera Collection, box 11, Huntington Library (hereafter cited as SBAEC). For similar arguments, see: "Women in the Home: How Far Can Mother Control These Things?" (Political Equality League, Los Angeles CA, 19-?), California Leaflets on Suffrage, volume 1, Huntington Library. Also, see Susan W. FitzGerald, "Women in the Home," Political Equality Series, National American Woman Suffrage Association 3:10 (1908): 3.

${ }^{71}$ Fitzgerald, "Women in the Home," 2. Though these pamphlets vary slightly, this exact phrase is also found in "Women in the Home: How Far Can Mother Control These Things?" (Political Equality League, Los Angeles CA, 19-?), California Leaflets on Suffrage, volume 1, Huntington Library.

${ }^{72}$ Maureen A. Flanagan, Seeing with their Hearts: Chicago Women and the Vision of the Good City, 18711933 (Princeton, NJ: Princeton University Press, 2002), 73-84; Gayle Gullett, Becoming Citizens: The Emergence and Development of the California Women's Movement, 1880-1911 (Chicago: University of Illinois Press, 2000), 151.

${ }^{73}$ Gullett, Becoming Citizens, 158, 164-65, 168-70; Graham, Woman Suffrage and the New Democracy, 33-36; Hobbs, "The World, Our Home," 1; Susan Goodier, No Votes for Women: The New York State 
Anti-Suffrage Movement (Urbana: University of Illinois Press, 2012), 41; Buechler, Women's Movements, 90102.

${ }^{74}$ McCammon and Campbell, "Winning the Vote in the West," 57 , argue that "gendered and political opportunities worked together with the ways in which the suffragists mobilized to convince male lawmakers and male electorates to extend democracy to women."

${ }^{75}$ McCammon and Campbell, "Winning the Vote in the West," 63-64, 74.

${ }^{76}$ Levenstein, Revolution, 42.

${ }^{77}$ Lisa Mullikin Parcell and Margot Opdycke Lamme, "Not 'Merely an Advertisement': Purity, Trust, and Flour, 1880-1930," American Journalism 29:4 (Oct. 2012): 99.

${ }^{78}$ Veit, Modern Food, Moral Food, 84; Lorine Swainston Goodwin, The Pure Food, Drink, and Drug Crusaders, 1879-1914 (Jefferson, NC: McFarland, 1999), 11-15; Thomas, In Food We Trust, chap. 1; Levenstein, Revolution, chap. 2; Elias, Food in the United States, 62.

${ }^{79}$ On how home economists avoided politics, see: Shapiro, Perfection Salad, 196-97.

${ }^{80}$ Clinton Political Equality Club, Choice Recipes, [title page].

81"Woman Suffrage Bazaar and Exhibition" (National American Woman Suffrage Association, 1912), Women's Suffrage Ephemera Collection, box 1, Bryn Mawr College Library (hereafter cited as WSEC); "Woman Suffrage Party: Mass Meeting at Domestic Science and Pure Food Congress" (Woman Suffrage Party, Nov. 1912), National American Woman Suffrage Association Records, 1894-1922, box 8, volume 26, folder 4, New York Public Library (hereafter cited at NAWSANYPL).

${ }^{82}$ Votes for Mothers, postcard, Oct. 1912, SBAEC, box 13.

${ }^{83}$ Alice Park to Louise Hall, July 31, 1912, Alice Park Papers, 1798-1953, box 4, folder 32, Huntington Library (hereafter cited as Park Papers).

${ }^{84}$ On suffragists arguing the vote was necessary to secure a pure milk supply see, for example, "Woman Suffrage Bazaar and Exhibition" (National American Woman Suffrage Association, 1912), WSEC, box 1; Molly Warren, "The Housekeeper's Need of the Ballot," The Yellow Ribbon (California) 1:8 (May 1907): 4; "Results of Equal Suffrage in California" (National Woman Suffrage Publishing Company, n.d.), SBAEC, box 6 , folder 2 .

${ }^{85}$ Mrs. Donald R. Hooker, "The Relation of Woman Suffrage to the Home and to Morality” (The Progressive Stenographer, n.d.), NAWSANYPL, box 8, vol 25, folder 3.

86،9,696 March For Cause of Women; Respect, Not Jeers, From Crowds," May 4, 1913, Harriet Burton Laidlaw Scrapbook; New York?: 1912-1914, New York Historical Society.

${ }^{87}$ Warren, "The Housekeeper's Need of the Ballot."

88“"Missouri: Why Club Women Indorse Woman Suffrage," New Southern Citizen (New Orleans) 1:2 (Nov. 1914): 8, Tulane University Archives.

${ }^{89}$ "Results of Equal Suffrage in California."

90“"The Suffragette," The Washington Herald (Washington, DC), Oct. 23, 1910, 4.

91“'Leading Men Take Up the Question on Women's Right to Vote," The New York Times, Dec. 20, 1908, 40.

${ }^{92}$ Finnegan, Selling Suffrage, 49, 86.

${ }^{93}$ Finnegan, Selling Suffrage, 119, 124; Kenneth Florey, Women's Suffrage Memorabilia: An Illustrated Historical Study (Jefferson, NC: McFarland \& Company, 2013), 85; "Wimodaughsis Cook-Book," The Woman's Tribune 8:43 (Dec. 19, 1891): 340; "Woman Suffrage Cook Book," The Woman's Journal 40:51 (Dec. 18, 1909): 208; “[untitled]," The Bemidji Daily Pioneer (Minnesota), Apr. 11, 1911, 2; "Woman's Suffrage Items," The Daily Review (Decatur, IL), April 13, 1911, 4.

${ }^{94}$ Henrietta W. Livermore, "How to Raise Money for Suffrage" (New York: National Woman Suffrage Publishing Company, 1917), 9. Also see: "Baking for Principle," New Southern Citizen (New Orleans) 1:3 (Dec. 1914): 10, Tulane University Archives.

${ }^{95}$ Anne Bower, "Our Sisters' Recipes: Exploring 'Community' in a Community Cookbook," Journal of Popular Culture 31:3 (Winter 1997): 138; Fisher, The American Cookbook, 56; Kennan Ferguson, "Intensifying Taste, Intensifying Identity: Collectivity through Community Cookbooks," Signs: Journal of Women in Culture and Society 37:3 (Spring 2012): 697-700; Janice Bluestein Longone, “'Tried Receipts': An Overview of America's Charitable Cookbooks" in Recipes for Reading: Community Cookbooks, Stories, Histories, ed. Anne Bower (Amherst: University of Massachusetts Press, 1997), 18-20. 
${ }^{96}$ Anne Bower, "Cooking up Stories: Narrative Elements in Community Cookbooks” in Bower, Recipes for Reading, 38, 40-41. Bower does not herself identify suffrage cookbooks as using these two plots; rather I argue that the plots she identifies (integration and differentiation) apply to suffrage cookbooks.

${ }^{97}$ Ferguson, "Intensifying Taste," 697.

${ }^{98}$ Bower, “Our Sisters' Recipes,” 150; Ferguson, "Intensifying Taste,” 713.

${ }^{99}$ Janet Theophano, "Home Cooking: Boston Baked Beans and Sizzling Rice Soup as Recipes for Price and Prejudice" in Inness, Kitchen Culture, 140.

100"Some Suffrage Cookery," The Palm Beach Post (Florida), Mar. 19, 1917, 23.

101 "Seeking Right Way to Influence His Vote," The San Bernardino County Sun (California), Feb. 18, 1917,6 .

102،"Gossip and Gleanings,” The Woman's Journal 23 (Feb. 20, 1892): 61.

${ }^{103}$ Ida Husted Harper, "What the Election Did for the Cause of Suffrage," New York Times, Nov. 10, 1912.

104"New York State Woman Suffrage Party Votes for Preparedness in the Home," 1.

105،An Equal Suffrage Cook Book,” The Woman's Journal 41:39 (Sept. 24, 1910): 157.

${ }^{106}$ Ross-Nazzal, Winning the West, 130.

${ }^{107}$ Ross-Nazzal, Winning the West, 7-9, 55, 130, 113.

108“Mrs. De Voe, Famous Woman," The Morning Standard (Ogden, UT), Nov. 27, 1910, 5.

109“'Suffrage Cookbook," Pittston Gazette (Pennsylvania), Aug. 31, 1909, 5.

110“"That Woman Suffrage Cook-Book," The Woman's Journal 17:43 (Oct. 23, 1886): 339.

${ }^{111}$ Burr, The Woman Suffrage Cook Book, iii.

112،The Woman Suffrage Cookery Book," The Woman's Journal 17:45 (Nov. 6, 1886): 358-59.

113“The Woman Suffrage Cookery Book," 358-59.

${ }^{114}$ Burr, The Woman Suffrage Cook Book, iv-vii, 42, 44, 112, 5.

${ }^{115}$ Suffrage Cook Book: A Collection of Recipes (Detroit, MI: The Equal Suffrage League of Wayne County, 1916); New York State Woman Suffrage Party Votes for Preparedness in the Home (191?); Clinton Political Equality Club, Choice Recipes Compiled for the Busy Housewife 1916 (Clinton, NY: The Courier Press, 1916), in private collection of Dr. Kenneth Florey; Ella M. S. Marble, ed., Wimodaughsis Cook-Book (Washington, DC, 1892), in private collection of Dr. Kenneth Florey; May Bartlett Shawhan Hoar, Enfranchised Cookery: An Offering from the Enfranchised Women Whose Names Appear Within to the Committee on Arrangements for the Forty-Seventh Annual Convention of the National American Woman Suffrage Association, December 14-15, 1915 (New York: National Woman Suffrage Publishing Company, 1915); "For Better Baking” (Rochester, NY: Political Equality Club of Rochester, 1913).

${ }^{116}$ Bower, "Cooking up Stories," 35-37.

${ }^{117}$ Kleber, The Suffrage Cookbook, 12-13.

118“"Cook Book Will Silence Enemy,” The Woman's Journal 46:41 (Oct. 9, 1915): 325.

119“'Dainty Dishes to Aid Suffrage: Enough Good Things in Equal Franchise Cook Book to Win Ballot: Women Leaders Kitchen Queens: Votes, Parade Planned for East Side-Programme for San Francisco Rally," New York Tribune, Sept. 12, 1915, 6.

${ }^{120}$ Mrs. Henry M. Youmans, et al., "Will Suffragists Neglect Home? Try These Recipes, Then Judge," The Milwaukee Leader, October 28, 1912, SBAEC, box 14.

121 "Dainty Dishes to Aid Suffrage," 6.

${ }^{122}$ Kleber, The Suffrage Cookbook, 57.

${ }^{123}$ Kleber, The Suffrage Cookbook, 148.

${ }^{124}$ H. B. B., "State Suffrage Cook-Book," The Woman's Journal 35:33 (Aug. 13, 1904): 260.

${ }^{125}$ Beverly Gordon, Bazaars and Fair Ladies: The History of the American Fundraising Fair (Knoxville: University of Tennessee Press, 1998), 1-5, 25, 31, 96, 98, 116, 123; Finnegan, Selling Suffrage, 116-18.

${ }^{126}$ Gordon, Bazaars and Fair Ladies, 121-22.

127“Woman's Suffrage Bazaar: Appearance of Pacific Hall—Curiosities-Etc.," San Francisco Chronicle, May 31, 1871, 1.

${ }^{128}$ Emphasis in original. Organizing to Win: The Political District Plan: A Handbook for Working Suffragists (New York: National American Woman Suffrage Association, 191-?), 13, 15.

129"Eastward The Star Of Suffrage Takes Its Way; Women Are Fighting In Four Atlantic Coast States This Year For The Right To Cast Ballot," The Fort Wayne Journal-Gazette, Mar. 14, 1915, 36. For examples of suffrage food for sale, see: "Franchise League Notes," The Indianapolis Star, Sept. 20, 1914, 38; "NO TIME TO BAKE," Times Herald (Olean, NY), Aug. 27, 1915, 7; "Lots of Good Things at Suffrage Food Sale," 
Harrisburg Telegraph, Feb. 10, 1914, 6; "Plan on Many Similar Meetings: Suffragists Delighted With Success of Rally at Hornung Farm: Activities of the Week as Reported to State Suffrage Headquarters," The Lincoln Star, Aug. 9, 1914, 19.

130"Variety of Cakes at Benefit Sale: Suffrage Women Will Show Their Ability as Housewives Next Tuesday," Harrisburg Telegraph, Feb. 6, 1914, 8.

131“Local Mention," The Oneonta Star (New York), Oct. 1, 1917, 5.

132“"Notes on Woman's Suffrage," The Labor World (Duluth, MN), June 26, 1915, 6.

133“"National Suffrage Notes," The Indianapolis News, Oct. 7, 1916, 19.

134،"The Atlanta Equal Suffrage Association," The Atlanta Constitution, Apr. 19, 1914, 8.

135“"Suffrage Bread Takes the Prize," The Woman's Journal 43:45 (Nov. 9, 1912): 360.

${ }^{136}$ Jablonsky, The Home, Heaven, and Mother Party, 129. 